\title{
Are State-Mediated Forms of Identification a Reaction to Physical Mobility? \\ The case of England, 1500-2007
}

\author{
Edward Higgs \\ University of Essex, UK \\ ejhiggs@essex.ac.uk
}

\begin{abstract}
The development of technologies of identification has been linked to mobility, urbanisation and anonymity in both past and contemporary societies. This paper looks at England over the past 500 years to see if the history of mobility, urbanisation and identification mesh chronologically. Looking at the legal person, the citizen and the criminal deviant in turn, it argues that only in the case of the latter does there seem to be such a relationship. Even here, however, there appear to be other factors at work as well. Rather than mobility per se as the causal factor, the development of forms of identification seems to be linked to the changing relationships between individuals, commercial organisation and the state.
\end{abstract}

\section{Introduction}

The identification of individuals is an issue that increasingly preoccupies governments and inter-governmental organisations across the world. In the aftermath of 9/11, an ability to identify people crossing national boundaries is a top priority for the international political community. The International Civil Aviation Organization, for example, has sought to introduce machine-readable biometrics into all passports used for international travel [34, pp. 49-51]. Internally, states seem obsessed with pinning people down administratively to prevent terrorism, benefit fraud, and identity theft, which threaten states, welfare systems and markets alike. In Britain this has led to the passage of the 2006 Identity Cards Act, which authorises the issuing of identity cards to all British citizens and others resident in the country. These are also to contain biometric information and, according to the British Home Office, are intended to:

- help protect people from identity fraud and theft;

- ensure that people are who they say they are;

- tackle illegal working and immigration abuse;

- disrupt the use of false and multiple identities by criminals and those involved in terrorist activity;

- ensure free public services are only used by those entitled to them; 
- enable easier access to public services [26].

Such developments are associated with an extensive raft of new identification technologies - DNA profiling, iris scanning, facial recognition systems, and so on.

The official drive to create foolproof means of identification has led to much public debate, and has been opposed by groups such as Liberty, the British civil liberties NGO [32]. In Britain, however, these public controversies have lacked, on the whole, an historical dimension. If identification is discussed in historical terms at all, media commentators usually go back no further than the national registration system of the Second World War [3]. Academic historians are, however, beginning to push back the history of identification into previous periods. One might include here Jane Caplan and John Torpey's excellent collection, Documenting Individual Identity [6], and Simon Cole and Chandak Sengupta's works on the introduction of fingerprinting in criminal forensics in the late nineteenth and early twentieth centuries [11; 48]. Sociologists, such as David Lyon in his The Electronic Eye, also attempt to place the surveillance of society in a temporal framework [35]. There are, in addition, a number historical works in which personal identification plays an incidental, but important, part, as in the recent biographies of impostors such as Perkin Warbeck and the Tichborne Claimant, and in Natalie Zemon Davis's The Return of Martin Guerre $[64 ; 38 ; 13] .{ }^{1} \quad$ However, these works do not try to explain how differing forms of identification have developed over time, but rather how identification failed in particular cases of imposture.

In many of these works there is a tendency to understand the development of identification in terms the impact of increased mobility, consequent upon processes of industrialisation, which are associated with urbanisation and increasing social anonymity. This is most clearly seen in Cole's Suspect Identities, in which he argues that:

In general, premodern societies already had an effective method of personal, and criminal, identification: the network of personal acquaintance through which persons were "known" in the memories and perceptions of their neighbors. Most people spent virtually their entire lives in the village, or region, in which they were born. ... In village society, there was little need for a signature to verify the identity of a neighbour. If a signature was used, it was more a gesture of good faith than a test of identity. ... In the wake of the industrial revolution, enormous numbers of people migrated from intimate rural villages to anonymous urban settings. Cities grew dramatically along with population density. The informal system of personal acquaintance and collective memory began to collapse $[11, \mathrm{p} .8]$.

Hence, Cole argues, the need for new forms of identification, such as the fingerprint, to deal with the rise of anonymity in society. Similarly, Sengupta in his

1 Perkin Warbeck claimed to be one of the 'Princes in the Tower' murdered by their uncle, Richard III, who raised rebellions against Henry VII. The Tichborne Claimant was an impostor who claimed to be the heir to an English aristocratic estate in the mid-nineteenth century. The case of Martin Guerre involved the trial of a man who had pretended to be a French soldier returned from the wars in sixteenth-century France. 
Imprint of the Raj, argues that fingerprinting can be seen within a context of urbanization and movement:

Nineteenth-century Europe was a haven for criminals. Life was becoming steadily more urban, anonymous and mobile - in the large cities, one could simply disappear into a milling crowd of individuals and take on new identities that the surveillance and policing methods of the time could not hope to detect $[48$, p.9].

Even Caplan and Torpey, who are fully aware of the complexity of this history, see the development of identification in the period of the French Revolution and its aftermath against 'the background of an increasingly mobile society in which older and more stable conventions of identification were dissolving...' [6, p.7].

Many of these arguments draw, in part, on classical sociological concepts, especially those found in Ferdinand Tönnies's Gemeinschaft und Gesellschaft. Originally published in 1887, this work contrasts the supposed communal life of the ancient rural community, the gemeinschaft, with forms of contractual association in modern urban society, the gesellschaft. In the gemeinschaft people supposedly work together, and are bound by ties of kinship, tradition and the common tilling of the soil. The gemeinschaft is an 'organic' entity in which feelings of love, habit and duty are said to combine to create harmony, and where individuals are known to each other personally. Conformity to established social conventions is maintained by the family, and by the habitual deference due to friends and neighbours. In the gesellschaft, or so Tönnies argues, all are strangers to each other, and people are orientated towards the fulfilment of personal goals and the making of money. In this form of society, others become mere tools to personal gain in a market economy. The state then acts as a means of keeping individuals from each other's throats, and enforces the rule of capitalists over the discontented working classes [55]. This concept of a 'society of strangers' is also found in the work of the early twentieth-century sociologist Georg Simmel [50]. The vision of a mobile, anonymous, society is plainly one in which official forms of identification become necessary to prevent fraud and to impose social control.

The discussions of political scientists with regard to the development of modern identification systems for tracking and limiting the movements of migrants and asylum seekers is similarly couched in terms of the mobility of contemporary global society. According to Didier Bigo contemporary techniques of identification passports, visas, identity cards - are merely a form of rhetoric, an illusion to give the impression that the nation state still has control over population flows in an era of economic globalisation, and of supra-national political structures such as the European Union [5; 1]. Stephen Castles, Professor of Migration and Refugee Studies at the University of Oxford, has also linked migration, security and surveillance [7, pp. 271-6]. Similarly, the sociologist David Lyon believes that, 'Mobility creates a world of nomads and unsettled social arrangements, so it is not surprising that in transit areas, such as airports, surveillance practices are intense' [36, p.19]. 


\section{Mobility, urbanisation and anonymity in England}

The equation 'modernity=mobility=anonymity=identification' which is found in much of this literature seems a fairly commonsensical one. Certainly the scale of cross border movements today would appear to require some forms of control mechanisms, however imperfect. According to Didier Bigo, for example, in the late 1990 s the European countries covered by the Schengen agreements (France, Germany, the Benelux countries, Spain and Portugal) experienced 1.7 billion border crossings each year [5, p.158]. But the question still needs to be asked as to whether this simple relationship can be shown to explain processes of change in the past, or the context of contemporary developments. To do this, the present paper looks at one European county, England, over the last 500 years to see if the development of forms of identification can be seen as meshing with the history of mobility, industrialisation, and urbanisation. As the birthplace of the Industrial Revolution, and one of the earliest urban societies, one might assume that this relationship would be close and early.

First, one needs to say something about mobility in England since the sixteenth century. Contrary to what one might assume, England in the early-modern period was not an immobile society. The work of historical demographers, especially those of the Cambridge Group for the Study of Population and Social Structure, has shown that village populations in the past were constantly changing. At Honiger in Suffolk, for example, of the 63 family names recorded in parish registers of baptisms, marriages and burials in the period 1600 to 1634 , only two could still be found in the registers for 1700 to 1724. Just over half the population of Cogenhoe in Northamptonshire disappeared and were replaced between 1618 and 1628. Whilst at Clayworth in Nottinghamshire the turnover of population between 1676 and 1688 approached twothirds, of which only one-third can be explained in terms of mortality. People were constantly moving in search of employment or of land in a nascent market economy [61, p.42]. Such turnovers of population can indeed be pushed back in England into the later medieval period [15, pp.14-15]. Such mobility may have been unusual in Europe in this period.

However, most of these movements were probably over fairly short distances, and varied by region, period and social class. Small landowners probably stayed put, whilst landless labourers moved to find jobs [60]. Moreover, once people had moved, they probably worked locally, since the development of the modern pattern of daily commuting between place of work and place of residence residence was a nineteenthcentury phenomenon [49, 117-57]. But those that had property had still to communicate over time and space through their wills and credit arrangements. They needed to prove their identity on documents that may have been created locally but needed to be lodged in various courts or in the money markets, often in London [39, pp.95-119]. The idea that early-modern Englishmen relied on trust in their commercial relationships is belied by the extreme litigiousness of the period.

Much of this movement was, of course, within the countryside, since it was only in 1851 that population censuses showed a majority of people in England living in settlements of 10,000 and over. However, there were certainly large urban 
conglomerates in England prior to that date. In 1600 England was less urbanised than the average for Europe as a whole but by 1800 it was the second most urbanised country, after the Netherlands. In the late eighteenth century, perhaps 70 per cent of the total urban growth in Europe as a whole was taking place in England [63, pp.2589]. Much of this urban growth could be found in the cities of the industrialising North and Midlands. Liverpool is estimated to have roughly trebled in size in the first four decades of the eighteenth century, and then increased more than fivefold between then and the end of the century, when its population stood at 82,000. By the end of the nineteenth century it was a conurbation of half a million. Birmingham, the centre of the metal industries, increased four and a half times between 1675 and 1760, and then doubled again by 1801 to 71,000 . It had reached half a million by 1901 [14,pp. 7-8; 12, pp.234-5].

But all these urban centres were overshadowed by London, which had a population of about half a million in 1700 , nearly one million in 1800 , and contained two and a half million people by the 1850s. Throughout this period, London was probably the largest city in the world [18, pp.330-34]. By 1901 the vast majority of English men and women lived in towns. This urban growth implied migration from the countryside since the high mortality of the cities meant that many could not sustain their own populations by endogenous births, never mind expand. Thus, according to E. A. Wrigley, in the later seventeenth century migration to London from the rest of the country alone absorbed about half of the total birth surplus outside the capital [62]. But these processes of urbanisation accelerated in the eighteenth and nineteenth centuries, and reached their peak in the period from 1850 to 1890 [31, p.5].

To this vast internal migration must be added the waves of foreign migration experienced by England in the nineteenth century. Much of the European emigrant population of the newly independent USA passed through British ports such as Liverpool and London. By 1842 nearly 200,000 people were emigrating to the USA via Liverpool, something like half of all migrants leaving Europe. Between 1830 and 1930 over nine million people sailed from Liverpool bound for a new life in the USA, Canada and Australia [33]. There were also huge movements of the Irish into Britain in the wake of the Potato Famine of the late 1840s. This migration led to the establishment of large immigrant populations in Britain, especially in British cities. According to the 1861 census, out of a population of 20 million, England and Wales contained 600,000 people born in Ireland, 169,000 born in Scotland, and 84,000 persons born in other countries, half the latter being in London [8, p.39]. Many of these would have had children born in England, so the ethnic immigrant population was in fact larger than these figures suggest.

In general terms, therefore, one might argue that population mobility has always been a feature of English society, although this probably accelerating in the eighteenth and nineteenth centuries with industrialisation and urbanisation. Similarly, although England only became a predominantly urban country in the nineteenth century, it had significant urban environments in the early-modern period. In this England was probably unique in Europe, and was a model that other European countries followed in the late nineteenth and twentieth centuries. 
English cities were certainly seen as anonymous places in the Victorian period but it is difficult to see such anonymity as anything new. Henry Fielding, the novelist and playwright, was complaining of the slums of London in the 1750s that,

Had they been intended for the very purpose of concealment, they could hardly have been better contrived. Upon such a view [London] appears as a fast wood or forest, in which a thief may harbour with great security as wild beasts do in the deserts of Africa or Arabia [27, p.25].

Such beliefs may explain why, with his brother John, Fielding set up the Bow Street Runners, one of the first official police forces in London. Similar complaints could be heard, of course, about the capital in the sixteenth century, as in Nicholas Harman's A Caveat for Common Cursitors. Harman, for example, describes in his book of 1567 the activities of a 'counterfeit crank' who posed as a impoverished and diseased beggar in one part of town but actually lived as a gentleman on his proceeds in another [47, pp.110-18]. Of course, such anonymity may have been class specific the urban poor may have been anonymous to the middle and ruling classes but familiar to each other. In Paris, for example, at the end of the eighteenth century, which was somewhat smaller than London but still had a population of perhaps half a million, there appears to have been no problem in identifying dead bodies pulled out of the Seine. The kin and neighbours of the dead were willing to come forward to identify them in the local morgue [10].

\section{Multiple personality in England}

Given this pattern of mobility and urbanisation, one would have expected the development of identification technologies in England to have taken place earlier than elsewhere, to be concentrated in the late eighteenth and nineteenth centuries, and to be strongly linked to mechanisms for social control. But is this, in fact, the case? However, before attempting to answer this question it is necessary to ask what is being identified by identification techniques. Although identification has always been applied to a human organism that acts, thinks and is embodied as an entity, that organism can be the bearer of multiple 'personalities' that can be identified in differing ways. Thus, returning to the uses of the new British identity card outlined above by the British Home Office, one can identify three sorts of personality that identification is intended to address:

1. the legal person who can own and alienate property, and enter into market transactions;

2. the citizen, or at least the person with a right to claim state welfare benefits;

3. the deviant criminal or alien who is to be the subject of control.

None of these personalities are natural; they are the product of social conventions since civil and administrative law does not exist in a state of brute nature. The legal person and the citizen are constituted as personalities by social practices imbedded in social interactions. One is a legal person because one can go to court to defend one's rights to property, and one is a citizen because one can make claims that the state recognises. The legal person and the citizen do not even need to have a body, since 
the dead can bequeath property via wills, or pass on pension rights. The criminal and the alien are treated as if they do not have such personalities, and do not therefore have some of these rights, or cannot make these claims.

In England these types of personality have historically been identified in very different ways. The legal person has tended to be identified by what he or she possesses, can do, or knows - seals, signatures, or PIN numbers. The citizen has tended to be identified via the community in the form of recognition by kin and neighbours, or through proof of official or commercial interactions. Only the criminal, and to some extent the alien, has been identified via the body, through branding, photography, fingerprinting, DNA profiling, and the like. Legal persons and citizens claim their identity, or have others claim it for them, only the deviant has an identity imposed upon them. It is partly the collapsing of these distinctions in the new identity card proposals, and in CCTV and online surveillance, that has raised public disquiet. So, taking these personalities separately, does the chronology of the development of forms of identification associated with them match the pattern of mobility and urbanisation noted above?

\section{The identification of the legal person in England}

In the case of the legal person the answer to this question probably has to be in the negative. The seal, for example, developed in England as a means of identifying the will of the legal person in the early middle ages. In Edward the Confessor's reign (1042-1066) only the king is known to have had a seal for authenticating documents, whereas in Edward I's reign (1273-1307) even serfs were required by statute law to have one. In the twelfth and thirteenth centuries the signature, or sign manual, was not accepted by itself as a lawful symbol of authentication on a document unless the signatory was a Jew. A Christian was required to either sign with a cross, indicating that he was making a promise in the sight of Christ crucified, or more commonly he affixed to the document his signum in the form of a seal [9, p.2, 233].

However, by the 1677 Statute of Frauds contracts had to be written and signed to be legal. The passage of this Act may possibly reflect the difficulty of proving rights to property in land in London after the disastrous Great Fire of London in 1666 had burnt down much of the old City [Hamburger]. One might also enquire if the shift away from the heraldic imagery of the seal, embodying the concept of the family estate, towards the personal performance of the signature, was not part of a larger trend towards possessive individualism in the period [37]. But after this date there were almost no innovations in the forms of legal identification until the late twentieth century. Then the introduction of automatic machine tellers (AMT) in London in 1967 necessitated the use of the first personal identification number (PIN), derived from the army number of the AMT's inventor, John Shepherd-Barron [4]. This seems to have been part of a reaction on the part of commercial organisations to a shift in the class basis of their customers. It is difficult to argue, therefore, that innovation in the identification of the legal personality had much to do with increased mobility during the eighteenth and nineteenth century. 


\section{The identification of the citizen in England}

Similarly, the identification of the citizen does not seem to have responded to this process. In terms of their rights, people tended in early-modern England to be recognised within their community. From the early sixteenth century, baptisms, marriages and burials had to be recorded in parish registers, giving bureaucratic form to the passage of the soul through the local Christian community [23, pp. 1-2]. This system was replaced in 1837 by the modern civil registration of births, marriages and deaths, but it was still the duty of next of kin or neighbours to report these events to the local civil registrar. The process generated a portable record of one's birth, the birth certificate, which became a means of identifying oneself. But this was still parasitic upon communal identification [44, pp.25-36]. Also, the original reason for introducing civil registration was not fear of personal mobility but of the insecurity of property rights under the old parochial system [23, pp.7-17]. Similarly, from the early middle ages onwards the bodies of persons found dead were identified in the coroner's court by the first person that came across them, the 'first finder' - usually a member of the family or a neighbour [28, pp.1-36].

This sense of local belonging was carried over into the Poor Law system established by various Acts of Parliament from the early sixteenth century onwards. In very simplistic terms, under these Acts each parish was tasked with looking after its own poor people, who were said to have a 'settlement' there. Parish overseers of the poor were responsible for raising a local tax, the 'poor rate', and for using this money to provide 'relief' to their neighbours who had fallen on bad times. The 'deserving poor' were identified through personal acquaintance. People who wondered about without a settled place of residence, 'vagrants' or 'vagabonds', were subject to various draconian penalties, culminating in death by hanging [51]. This system did not prevent mobility because one could obtain a settlement via residency and employment in another parish for a particular period. To make certain of their position under the Poor Laws, the mobile poor could obtain a 'settlement certificate' from their parish of settlement, indicating their right to poor relief there, that they presented to the overseers in their new home. Such identity papers meant that the receiving parish was thus guaranteed that the incoming person could be sent back to their parish of settlement for relief [52, pp.98-105].

This highly localised sense of belonging remained the basis of rights to welfare throughout the nineteenth century. In the countryside overseers of the poor continued to provide poor relief to their neighbours in their homes into the twentieth century. In the urban conurbations the increasing lack of personal knowledge of the poor by Poor Law officials did not lead to new forms of identification but to the 'workhouse test'. Under the 1834 New Poor Law Act, 'out-relief' of the poor in their own homes was supposedly outlawed, and those receiving relief had to do so in workhouses - virtual prisons in which they were put to work. This was mainly ignored in the countryside but not in the towns, where the poor had to present themselves at the workhouse door to claim relief. The urban poor had to identify themselves by a physical application for relief, rather than through carrying a means of identification [52, pp.207-338]. Indeed, rather than expanding the use of the settlement certificate as a means of 
identification, their issue by local Poor Law authorities seems to have ceased in the early nineteenth century [K. D. M. Snell, personal communication, 27/6/2006]. Thus, the increased mobility of the population in this period does not appear to have led to the development of new forms of identification.

In the Edwardian period the Poor Laws began to be superseded by centrally paid welfare payments such as old age pensions and national insurance. The 1908 Old Age Pensions Act gave the elderly pensions of $1 \mathrm{~s}$ to $5 \mathrm{~s}$ per week, provided that they did not receive poor relief after 1 January 1908; had not been imprisoned for any offence, including drunkenness, during the ten years preceding their claim; were not aliens or the wives of aliens; and could satisfy the pension authorities that they had not been guilty of 'habitual failure to work according to his ability, opportunity, or need, for his own maintenance or that of his legal relatives'. In all, less than 500,000 people received the benefit [54, p.103]. The national insurance system established by the 1911 National Insurance Act paid out limited unemployment benefits, and was at first only open to a small number of trades such as shipbuilding, engineering and construction. These covered about 2.5 million workers, out of a total male labour force of slightly over 10 million. By design, such trades included almost no women; were skilled and well-organised and provided stability of personnel; did not, by custom, see men being put on short-time during a depression; and, it was hoped, were trades subject only to reasonable and predictable seasonal fluctuations. National insurance also offered sickness benefits and basic medical care to those earning less than a specified annual income but not to their families and dependants. The system was administered by centrally-registered approved societies - friendly societies, commercial insurance companies, and some trade unions [19, p. 53, 88] [59]. In the course of the twentieth century the payment of such benefits expanded into the modern Welfare State.

Although this new form of centralised welfare led to the creation of vast systems of centralised record keeping [24, pp.118-23], this does not appear to have led to a shift in identification practices. The identity of claimants was still proven through their links with others in the locality. In order to determine the claims of old age pensioners the local pensions officer was advised to get references from former employers, and 'respectable people on whose word reliance can be placed'. They could fall back on local 'poor law officials, ministers of religion, clerks to the justices, petty session clerks, collectors of rates, police officials, shopkeepers, or officials connected with friendly and other provident societies or with trade unions' [40, p.301]. People claiming unemployment benefits had to be certified by their late employers [41]. Similarly, the dependents of soldiers with children claiming war pensions had to be certified by persons of rank who 'believe her to be the person she represents herself to be', that is, ministers of religion, magistrates, physicians or surgeons, officers of HM services, school headmasters, secretaries of friendly societies, postmasters/mistresses, or police officers [42]. By the late twentieth century benefit claimants had to provide a wide range of documents showing that they were enmeshed in networks of social and official relations - tax forms, driving licences, contracts of employment, payslips, invoices and the like. The birth certificate could be supplied as proof of identity but it was not the only document allowed. 
New systems for the identification of citizens for welfare purposes were introduced in Britain during wartime. During both World Wars identification cards and certificates were issued to the population as part of national registration for conscription purposes. They were also used for rationing in the First and Second World Wars, and for the claiming benefits in the latter, and in its immediate aftermath. But the system was wound up in 1952, and not resurrected until the early twenty-first century [24, p.134-44]. Similarly, from time to time the concept of a benefit payment card has been mooted as a means of identification for welfare claimants but trials of these have come to nothing [43]. Once again, few of these developments seem to reveal a quantum leap in the forms of identification used by citizens as a consequence of increased mobility.

Similarly, the history of the international passport fails to show a close correspondence with population mobility. The passport has had a long history in Europe, going back to the late middle ages. However, during the nineteenth century people moved into and out of Britain with few restrictions, and the use of passports declined generally throughout Europe [21, pp.156-64, 235]. This system of laissez faire was not abandoned because of population mobility, rather it was a victim of democracy and the First World War. With the expansion of voting rights to the working population in the late nineteenth century, immigration, especially into the East End of London, became a political issue that right-wing politicians could mobilize in search of votes. The 1905 Aliens Act began the process of tightening up foreign immigration [16, pp.69-73, 170-98]. With the outbreak of war, the 1914 Aliens Restriction Act passed in August of that year, gave the government still greater powers to restrict such movement. This increasing sensitivity to perceived threats from abroad was shared by states across the developed world, and led to the creation of the modern system of international passports. The first modern United Kingdom passport was issued in 1915 when the 1914 Status of Aliens Act came into force. The new passport contained the personal description of the holder, giving the shape of the person's face, their features (nose: large, forehead: broad, eyes: small) as well as their complexion, a photograph, and their signature [57]. The wartime restrictions were extended after the period of conflict by the Aliens Order of 1920, that laid down that anyone wanting to enter or leave the country had to carry a passport indicating his or her nationality and identity. In a world in which citizens were being mobilised for total warfare, all foreign nationals became a potential threat [56]. What was important here was the nature of the relationship between the state and the citizen, rather than mobility per se.

\section{The identification of the deviant in England}

Given the importance attached to the identification of the deviant in the current historiography of identification, one might expect this facet of personal identification in England to reveal the closest meshing with increasing mobility and urbanization. To some extent this is the case. Certainly, the nineteenth century saw a number of innovations in forensic identification in England. Registers of distinctive marks 
began to be compiled by the new uniformed police forces set up in the period, supplemented by the development of the photographic 'mug shot' from the mid Victorian period onwards. A Habitual Criminals Registry was set up by the Metropolitan Police as a consequence of the 1869 Habitual Criminals Act that imposed extra punishments on repeat offenders. The Registry eventually came to introduce fingerprinting as the main form of criminal identification in the Edwardian period, after briefly experimenting with the 'anthropometric system'. The latter, developed by Alphonse Bertillon in Paris, involved recording the measurements of limbs and facial features of criminals. In the twentieth century such means of forensic identification were supplemented by serology, facial reconstruction, and, of course, DNA profiling [24, pp. 95-7, 113-18, 182-3].

Such developments can thus be placed in the context of the broad picture of mobility, urbanization and anonymity in England. However, the lack of any significant innovations in the eighteenth and early nineteenth centuries seems somewhat problematic given the Industrial Revolution of this period. There were also deep continuities. The criminal in England had always been identified via the body from the early-modern period onwards. Vagrants under the Old Poor Laws could be branded, whilst the physical descriptions of felons were circulated in newspapers, and on posters, from an early date [53]. The development of the criminal registry, and the capture of the likeness of the criminal, can be found in Europe in the medieval period [21,pp. 69-77]. Moreover, suggestions that such forms of physical identification should be extended to the legal person or the citizen were generally rejected in the English context until the recent passage of the Identity Cards Act.

There were also other forces at work here than a simple reaction to increasing mobility. It has been suggested, for example, that the moral panics over crime in the Victorian period did not represent a rational reaction to increasing crime levels, since the increasing number of criminal indictments merely reflected the increasing activities of the police [17]. What was more fundamentally at stake was the desire of the middle classes, who had won increased political power in the 1832 Reform Act, to control the 'criminal classes', especially in the aftermath of the French Revolution [46]. This can be seen as part of a much wider bourgeois attempt to infuse order into the urban landscape [29]. The passing of the Habitual Criminals Act can, in a sense, be seen as a result of the restriction of the mobility of criminals. It was the ending of the transportation of convicts to the Australian colonies that created the fear of a sedentary criminal class in England, and so prompted the creation of a more draconian penal system [25, cols. 332-45]. Similarly, the 1869 Habitual Criminals Act might be understood, in part, as a reaction to the passing of the 1867 Reform Act, which gave voting rights to many working-class men. The criminal could no longer be seen simply as a member of the lower orders, he or she had now to be reconceptualised as a degenerate sub-culture beyond the constitutional pale [58, pp. 300-6, 342-58]. One might even argue that criminality had to be raised to the level of a social pathology in order to justify the vast network of police and prisons in a liberal society [30, pp. 296308].

Yet again, the origins of modern fingerprinting lay not in Britain's industrializing cities but in rural Hampshire and British India. In the late 1860s and early 1870 s 
probably the most infamous man in Britain was the Tichborne Claimant, a butcher from Wagga Wagga in Australia who claimed to be Sir Roger Tichborne, the heir to the Tichborne estates in Hampshire, who had been lost at sea in 1854. The Claimant was eventually unmasked as an imposter but only after two inordinately long and costly court trials $[2 ; 38]$. The cases involved a vast range of identification evidence eye witness testimony, photographs, tattoos, hair samples, and even the size of the Claimant's penis - much of which was inconclusive. This attack on property rights led to a desire to discover a foolproof method of personal identification, and thus to the work of Sir Francis Galton on fingerprint identification. Galton, a redoubtable Victorian polymath, wrote extensively on the subject but his classification system for fingerprints was too cumbersome to be easily used in forensics [20, pp.231-49]. The classification which was eventually introduced into British police work in the early twentieth century came out of the experience of police work in British India. Given the British assumption that all Indians were dishonest, and could not be distinguished from each other, fingerprinting did represent a reaction to anonymity but in a particular racial and imperial context [48].

In sum, although there seems to be a prima facie correspondence between the history of mobility in England and forms of identification for criminals, the causal link becomes less apparent on closer inspection.

\section{Towards a conclusion}

Many aspects of the need for personal identification in the contemporary world are plainly linked to mobility. This is most obviously seen in the case of the tracking of international terrorists and criminals. However, an examination of the history of identification in England over the past 500 years shows that this has not always been the case. The developments in the identification of the legal person and the citizen do not appear to follow the chronology of changes in patterns of mobility. Indeed, in the nineteenth century, when mobility was increasing, there was little innovation in these fields, and, in some respects, a curtailment of identification practices. In the twentieth century the movements of citizens were controlled via the passport system but this represented a new relationship between the state and the citizen. States came to see citizens of other states as potential enemies in an age of total military mobilization, whilst their own citizens saw their citizenship as a patrimony that needed to be defended against immigrants. In the case of the identification of the criminal the chronologies do mesh more closely, although the absence of innovations in the eighteenth and early nineteenth centuries is problematic. Moreover, it is not always clear that changes in criminal identification in the late nineteenth and twentieth centuries can be seen simply in terms of mobility.

This, of course, raises the question as to why the British state has suddenly decided that the distinctions between the identification of legal persons, citizens and deviants needs to be effaced. Rather than seeing this simply as the cumulative effect of population mobility, urbanization and anonymity, one might have to look for changes in the relationship between the state and civil society. In England in the 
modern period the state has generally trusted civil society to go about its business unhindered. As long as citizens obeyed the law, and accepted the market economy, the party political system, and the territorial integrity of the United Kingdom, they were generally left to get on with their lives. Legal persons could be trusted to maintain their own forms of identification, and communities and social interactions could be used to prove the identity of welfare claimants. But relationship is now being undermined, possibly reflecting the decline in inter-personal trust that has been a general feature of Western society in the post-war period [45, pp.121-31]. The state no longer believes that civil society can be trusted with many facets of identification. This is a fundamental shift in the relationship between the government and the governed, and seems to have comparatively little to do with mobility per se.

\section{References}

1. Malcolm Anderson, Didier Bigo, Ed Bort, 'Frontiers, identity and security in Europe, an agenda of research', in Martin Pratt and Janet Allison Brown (eds), Borderlands Under Stress (London: Kluwer Law International, 2000), pp. 251-74.

2. Robyn Annear, The Man Who Lost Himself. The Unbelievable Story of the Tichborne Claimant (London: Robinson, 2002).

3. BBC News Website 1: 'When the British fought off ID cards', http://news.bbc.co.uk/1/hi/magazine/3129302.stm (9/7/2007).

4. BBC News Website 2: http://news.bbc.co.uk/1/hi/business/6230194.stm\#toolbar (13/7/07).

5. Didier Bigo, 'Frontiers and security in the European Union: the illusion of migration control', in Malcolm Anderson and Eberhard Bort (eds.), The Frontiers of Europe (London: Pinter, 1998), pp 148-64.

6. Jane Caplan and John Torpey, Documenting Individual Identity. The Development of State Practices in the Modern World (Princeton: Princeton University Press, 2001).

7. Stephen Castles and Mark J. Miller, The Age of Migration (Basingstoke: Palgrave Macmillan, 2003).

8. Census of England and Wales, 1861, General report [Vol. III.], British Parliamentary Papers 1863 LIII (3221).

9. M.T. Clanchy, From Memory to Written Record: England 1066-1307 (Oxford: Blackwell Publishing, 1993).

10. Richard Cobb, Death in Paris 1795-1801 (Oxford: OUP, 1978).

11. Simon Cole, Suspect Identities. A History of Fingerprinting and Criminal Identification (Cambridge, MA: Harvard University Press, 2001).

12. Chris Cook and Brendan Keith, British Historical Facts 1830-1900 (New York; St Martin's Press, 1975).

13. Natalie Zemon Davis, The Return of Martin Guerre (Cambridge, MS: Harvard University Press, 1983).

14. Phyllis Deane and W. A. Cole, British Economic Growth 1688-1959 (Cambridge: Cambridge University Press, 1969).

15. Christopher Dyer, 'Were late medieval English villages 'self-contained', in Christopher Dyer (ed.), The self-contained village? The social history of rural communities 1250-1900 (Hatfield: University of Hertfordshire Press, 2007), pp. 6-27.

16. Bernard Gainer, The alien invasion : the origins of the Aliens Act of 1905 (London : Heinemann Educational Books, 1972). 
17. V. A. C. Gatrell and T. B. Hadden, 'Criminal statistics and their interpretation', in E. A. Wrigley (e.d) Nineteenth-Century Society. Essays in the Use of Quantitative Methods for the Study of Social Data (Cambridge: Cambridge University Press, 1972), pp. 336-396.

18. Robert Gray, A History of London (London: Hutchinson, 1978).

19. Bentley B. Gilbert, British social policy 1914-1939 (London: B.T.Batsford, 1970).

20. Nicholas Wright Gillham, A Life of Sir Francis Galton: from African Exploration to the Birth of Eugenics (Oxford: Oxford University Press, 2001).

21. Valentin Groebner, Who are you? Identification, deception and surveillance in early modern Europe (Brooklyn, NY: Zone Books, 2007).

22. Philip Hamburger, 'The conveyancing purposes of the Statute of Frauds', American Journal of Legal History, 27 (1983), pp. 354-85.

23. Edward Higgs, Life, Death and Statistics: Civil Registration, Censuses and the work of the General Register Office, 1837-1952, (Hatfield, Local Population Studies, 2004).

24. Edward Higgs, The Information State in England. The Central Collection of Information on Citizens since 1500 (Basingstoke: Palgrave Macmillan, 2004).

25. Hansard's Parliamentary Debates, $3^{\text {rd }}$ series, Vol. CXCIV.

26. Home Office Website: http://www.homeoffice.gov.uk/passports-and-immigration/idcards/why-we-need-id-cards/ (9/7/2007).

27. Robert Hughes, The fatal shore. A history of the transportation of convicts to Australia, 1787-1868 (London: Guild Publishing, 1987).

28. R.F. Hunnisett, The Medieval Coroner, (Cambridge: Cambridge University Press, 1961).

29. Patrick Joyce, The Rule of Freedom. Liberalism and the Modern City (London: Verso, 2003).

30. Michel Foucault, Discipline and Punish. The Birth of the Prison (London: Allen Lane, 1977).

31. Eric E. Lampard, 'The urbanizing world', in H. J. Dyos and Michael Wolff (eds), The Victorian City: Images and Realities, Volume I (London: Routledge \& Kegan Paul, 1976), pp. 3-58.

32. Liberty Website: http://www.liberty-human-rights.org.uk/issues/3-privacy/31-idcards/index.shtml (9/7/2007).

33. Liverpool Maritime Archives \& Library Sheet No. 64 : Liverpool and Emigration in the 19th and 20th Centuries http://www.liverpoolmuseums.org.uk/maritime/archive/displayGuide.aspx? (12/7/2007).

34. London School of Economics, The Identity Project. An Assessment of the UK Identity Cards Bill and its Implications (London: LSE, 2005).

35. David Lyon, The Electronic Eye. The Rise of Surveillance Society (Cambridge: Polity Press, 1994).

36. David Lyon, Surveillance Society. Monitoring Everyday Life (Buckingham: Open University Press, 2001).

37. C. B. Macpherson, The Political Theory of Possessive Individualism. Hobbes to Locke (Oxford: Clarendon Press, 1962).

38. Rohan McWilliam, The Tichborne Claimant. A Victorian Sensation (London: Hambledon Continuum, 2007).

39. Craig Muldrew, The Economy of Obligation. The Culture of Credit and Social Relations in Early Modern England (Basingstoke: Macmillan, 1998).

40. National Archives, London: Board of Inland Revenue and Board of Customs and Excise: Non Contributory Old Age Pensions, Registered Files (AST 15):AST 15/64 Old Age Pensions Acts 1908 and 1911: Instructions to Pension Officers; proofs 1911-1913. 
41. National Archives, London: Ministry of Labour and successors: Circulars and Codes of Instructions (LAB 29): LAB 29/237 Instructions regarding investigations of claims 1936.

42. National Archives, London: Ministry of Pensions and successors: War Pensions, Registered Files (GEN Series) and other records (PIN 15): PIN 15/1352 Identification of Pensioners 1917-1923.

43. National Audit Office, The Cancellation of the Benefits Payment Card Project, http://www.nao.org.uk/publications/nao_reports/9900857.pdf.

44. Muriel Nissel, People Count. A History of the General Register Office (London: HMSO, 1987).

45. Avner Offer, The Challenge of Affluence. Self-Control and Well-Being in the United States and Britain since 1950 (Oxford: Oxford University Press, 2006).

46. David Philips, 'A new engine of power and authority': the institutionalisation of lawenforcing in England 1780-1830', in V Gatrell, B Lenman, and G Parker (eds), Crime and the law: the social history of crime in Western Europe since 1500 (1980), pp. 155-89.

47. Gamini Salgado (ed.), Cony-Catchers and Bawdy Baskets (Harmondsworth: Penguin, 1972).

48. Chandak Sengoopta, Imprint of the Raj. How Fingerprinting was Born in Colonial India (London: Macmillan, 2003).

49. Francis Sheppard, London 1808-1870: the Infernal Wen (London: Secker \& Warburg, 1971).

50. George Simmel, The Stranger (Chicago: Chicago University Press, 1971).

51. Paul Slack, Poverty and Policy in Tudor and Stuart England, (London: Longman, 1988).

52. K. D. M. Snell, Parish and Belonging. Community, Identity, and Welfare in England and Wales, 1700-1950 (Cambridge: Cambridge University Press, 2006).

53. John Styles, 'Print and policing: crime advertising in $18^{\text {th }}$ century England', in Douglas Hay and Francis Snyder (eds), Policing and prosecution in Britain 1750-1850 (Oxford: Clarendon Press, 1985), pp. 55-112.

54. Pat Thane, 'Non-contributory versus insurance pensions 1878-1908', in Pat Thane (ed.), The origins of British social policy (London: Croom Helm, 1978), pp. 84-106.

55. Ferdinand Tönnies, Community and civil society (Gemeinschaft und Gesellschaft) (Cambridge: CUP, 2001).

56. John Torpey, 'The Great War and the birth of the modern passport system', in Jane Caplan and John Torpey (eds), Documenting individual identity. The development of state practices in the modern world (Princeton: Princeton University Press, 2001), pp. 256-70.

57. UK Passport Service Website: http://www.ukpa.gov.uk/_history/history_03.htm (7 May 2002).

58. Martin J. Weiner, Reconstructing the Criminal.Culture, Law, and Policy in England, 18301914 (Cambridge: Cambridge University Press, 1990).

59. Noel Whiteside, 'Private provision and public welfare: health insurance between the wars', in David Gladstone, Before Beveridge. Welfare before the Welfare State (London: IEA Health and Welfare Unit, 1999), pp. 26-42.

60. Jane Whittle, 'Population mobility in rural Norfolk among landowners and others c.1440c.1600', in Christopher Dyer (ed.), The self-contained village? The social history of rural communities 1250-1900 (Hatfield: University of Hertfordshire Press, 2007), pp. 28-45.

61. Keith Wrightson, English Society, 1580-1680 (London: Routledge, 1993).

62. E. A. Wrigley, 'A simple model of London' s importance in changing English society and economy 1650-1750, Past and Present 37 (1967), pp. 44-70.

63. E. A. Wrigley, Poverty, Progress and Population (Cambridge: Cambridge University Press, 2004). 
Edward Higgs

64. Ann Wroe, Perkin. A Story of Deception (London: Vintage, 2004). 